\title{
Lithofacies characterization of fluvial sandstones from outcrop gamma-ray logs (Loranca Basin, Spain): the influence of provenance
}

\author{
A. W. Martinius ${ }^{1,2}$, C. R. Geel ${ }^{1}$ and J. Arribas ${ }^{3}$ \\ ${ }^{1}$ Delft University of Technology, Faculty of Cuirl Engineering and Geosciences, Subfaculty of Technical Earth Sciences, \\ Mijnbounstraat 120, PO Box 5028, 2600 GA Delft, The Netherlands \\ ${ }^{2}$ Present address: Statoil's Research Centre, Arkitekt Ebbells veg 10, Rotvoll, N-7005 Trondheim, Norvvay \\ (e-mail:anma@statoil.com) \\ ${ }^{3}$ Universidad Complutense de Madrid, Facultad de Ciencias Geologicas, Departamento de Petrologia y Geoquimica \\ 28040 Madrid, Spain
}

\begin{abstract}
Natural gamma spectral (NGS) $\log$ møtifs and cluster analysis were

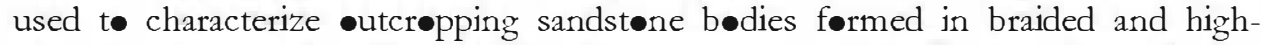

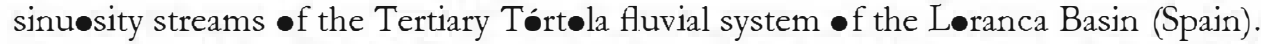

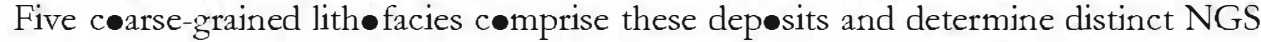

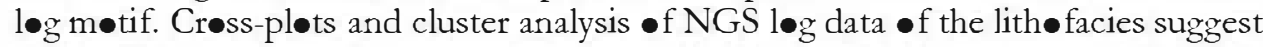
three distinct clusters. These clusters reflect distinct values for sandstenes with small sets -f ripple lamination, cross-stratification, and conglomerates and pebbles. Ripple-laminated sandstenes shøw the mest variability in NGS signature, whereas

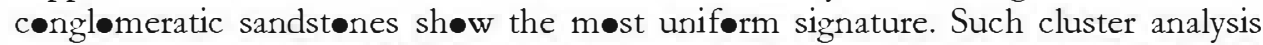

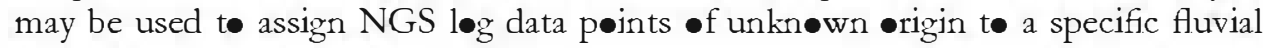

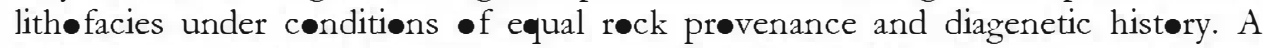
sedimentaclastic (i.e. sedimentary parent røck) •rigin $\bullet$ f sediments appears t• be the

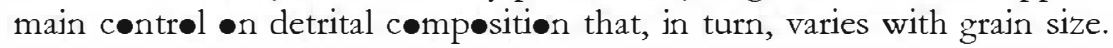

KEYWORDS: gamma ray logeing fuvial sandstone body, provenance, reservoir characteristic

\section{INTRODUCTION}

The shape of a natural gamma spectral (NGS) log is determined by the natural radioactivity of the rock constituents (if such factors as borehole eccentricity and tool characteristics in well bore environments are neglected). Minerals like quartz, gypsum and calcite typically have negligible radioactivity, whereas clays like illite and monazite are highly radioactive. NGS log motif is commonly interpreted in terms of grain size change and diagenetic effects (Rider 1996). The relation between the grain size and NGS value of a sandstone facies is complex because grain constituents and clay matrix abundance also varies. In the subsurface, additional petrophysical lozging tool information is required to adequately define lithofacies.

Adams \& Weaver (1958) and Serra et al. (1980) were among the first to outline the use of NGS cross-plots for the identification of clay minerals. The amount of potassium (K), thorium (Th) and uranium (U) were assumed to be associated with specific minerals that can be used as indicators of the sediment source areas. Rider (1990, 1996), Hurst (1990) and Hurst \& Milodowski (1996) have commented on pitfalls of overly rigid interpretations of NGS data to define depositional systems. Many factors influencing the chemical behaviour of $\mathrm{K}$, Th and $U$ are not yet well understood or quantied and are likely to vary in different sedimentary and diagenetic settings. More importantly, chemical data for clay minerals including $\mathrm{K}$, Th or $\mathrm{U}$, lack a firm statistical base and are mostly derived from non-reservoir or outcrop-specific ore deposits (Hurst 1990; Hurst \& Milodowski 1996).
The application of natural gamma spectrometry as an outcrop exploration tool dates from the early 1970s (Cassidy 1981). Several clastic facies studies incorporated outcrop measurements with hand-held or truck-mounted NGS tools (Chamberlain 1984, comments by Cowan \& Myers 1988; Myers \& Bristow 1989; Jordan et al. 1991; Dypvik 1993; North \& Boering 1999).

This study aims to define relationships between outcropping fluvial lithofacies formed in different depositional settings and NGS log ing values, and to evaluate the influence that detrital composition of lithof acies may exert on NGS values. Identification of mineralogy from the NGS log data is not our goal. NGS log responses measured in different sandstone lithofacies were examined spatially and by 3D NGS cross-plots.

\section{GEOLOGICAL SETTING}

The fluvial sandstone bodies studied are part of the upper Oligocene to lower Miocene Tórtola fluvial system (Loranca Basin, central Spain; Fiz. 1). These deposits are well exposed, and their depositional setting is well understood (Díaz-Molina et al. 1989, 1995; Hartkamp et al. 1993; Arribas et al. 1995, 1996; Martinius 2000; and a series of papers on the Tórtola fluvial system in Friend \& Dabrio 1996).

The deposits of the Tórtola fluvial system are sedimentaclasic (i.e. from sedimentary parent rock) in origin, generated during the most active infill stage of the Loranca Basin, a continental, so-called 'non-sequenced' foreland basin (Gómez et al. 1996). Such a foreland basin is typified by both a forward 


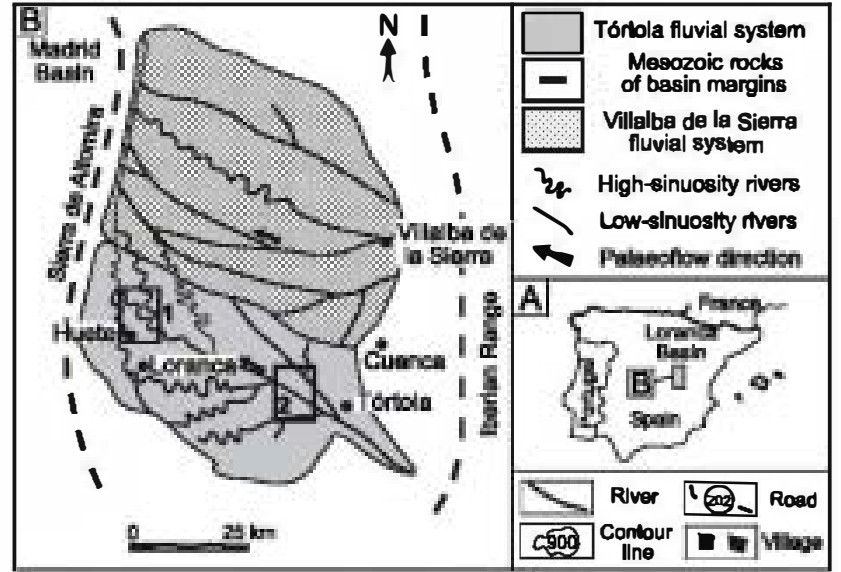

Fig. 1. (A) Schematized location map of Spain and (B) the position -f the Loranca Basin (medified after Díaz-Mølina et al. 1989). The boxed areas 1 and 2 refer to the distal and medial study areas shown in Figure 2. The rivers shøwn are the apprøximate pøsitiøns $\bullet \bullet$ -f the main palaeechannels.

(or pizyback) sequence of thrusting, and a backward thrust sequence during subsequent phases of foreland basin development. The provenance of the deposits of the Tórtola fluvial system is related to the erosion of a Mesozoic succession of sedimentary rocks (close to $2600 \mathrm{~m}$ in thickness) cropping out in the Iberian Range (Fig. 1). This succession is formed by Triassic siliciclastics (arkosic sandstones and illitic mudstones) and dolostones, and Jurassic to Cretaceous limestones, dolostones, marls and sandstones (subarkosic sandstones to quartzarenites). The Tórtola deposits have only been affected slightly by diagene processes such as mechanical compaction, calcite cementation and occasional framework dissolution.

\section{METHODOLOGY}

Outcrop NGS measurements were made along vertical profiles on exposed sandstone cliff faces using a hand-held portable Scintrex Gad-6 spectrometer. This tool measures simultaneously integral (total counts) and differential $(K$, Th, and $U$ counts) gamma radiation (see Appendix A and B).
Data were collected at axial and marginal positions within different types of palaeochannel fills. Palaeochannel orientation, direction of palaeoflow, and the distribution of lithofacies and bounding surfaces were also recorded. The sedimentological characteristics and morphology of the exhumed sandstone bodies have been studied following the procedures outlined by Cuevas Gozalo \& Martinius (1993). Outcrops were selected based on preserved sandstone-body thickness, degree of exposure and accessibility.

In addition, we have analysed 27 samples of sandstones and conglomerates corresponding to the five considered lithofacies, following the traditional methods of analysis in thin sections that include a point-count analysis of framework, matrix and cement components. Statis real results are summarized in Table 1. An unpublished petrological dataset (Arribas \& Tortosa, pers. comm.) has been used to complement sandstone compositional data.

\section{DISTRIBUTION OF RADIOACTIVE $\mathrm{K}$, TH AND U}

Potassium is common in feldspar (notably $\mathrm{K}$-feldspar) and in mica. Potassium can be common in clays like illite, but is rare in other clays like kaolinite in which the $\mathrm{K}$ content has no relation to its mineral chemistry (Eslinger \& Pevear 1988; Hurst 1990). $\mathrm{K}$ tends to form discrete authigenic minerals of silt-size rather than adsorb on kaolinite surfaces; a process closely related to diagenesis.

Thorium is stable under oxidizing conditions and generally does not pass into solution. It occurs in feldspars and detrital heavy mineral grains, mainly monazite (Hurst \& Milodowski 1996) and thorite (which are often classed as micas). It is generally held that Th adsorbs on to the surface of clay minerals such as kaolinite and chlorite, a process that may take place during weathering deposition or diagenesis. The Th content, therefore, is assumed to vary depending on the presence of Th-bearing detrital minerals, the availability of dissolved Th in pore waters and the adsorption capacity of mineral surfaces. Hurst (1990), however, found that kaolinite has a very low adsorption capacity, relative to micaceous minerals and similar to quartz. Hurst \& Milodowski (1996) concluded that Th is associated with chemically resistant minerals. Th shows an

Table 1. Modal sand composition of the five sandstone lithofacies divided into five grou ps

\begin{tabular}{|c|c|c|c|c|c|c|c|}
\hline & \multirow{2}{*}{$\begin{array}{l}\text { Conglomerate and } \\
\text { pebbly sandstone } \\
\text {-f multistorey } \\
\text { bodies }(n=2)^{2}\end{array}$} & \multirow{2}{*}{$\begin{array}{l}\text { Large avalanche } \\
\text { foresets of giant- } \\
\text { bar sandstone } \\
\text { bodies }(n=4)\end{array}$} & \multicolumn{2}{|c|}{$\begin{array}{l}\text { Large rough-shaped sets of cross- } \\
\text { stratified sandstone of ribbon bodies }\end{array}$} & \multicolumn{2}{|c|}{$\begin{array}{c}\text { Small trough-shaped sets of crøss- } \\
\text { stratified sandstone of single point-bar } \\
\text { bodies }\end{array}$} & \multirow{2}{*}{ 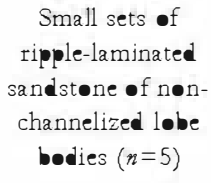 } \\
\hline & & & Bett•m $(n=4)$ & Tøp $(n=4)$ & B•tt•m $(n=4)$ & T॰p $(n=4)$ & \\
\hline NCE & $78.8 \pm 9.5$ & $66.3 \pm 8.9$ & $69.4 \pm 15.2$ & $54.1 \pm 11.3$ & $67.8 \pm 6.2$ & $60 \pm 5.8$ & $61.7 \pm 2.5$ \\
\hline$C E$ & $10.4 \pm 2.2$ & $25.3 \pm 6.1$ & $16.6 \pm 4.5$ & $21.4 \pm 8.8$ & $19.3 \pm 8.5$ & $16.3 \pm 5.3$ & $16.8 \pm 2.5$ \\
\hline $\mathrm{CI}$ & $10.8 \pm 7.4$ & $8.4 \pm 4.1$ & $14.4 \pm 17$. & $24.5 \pm 18.3$ & $12.9 \pm 8.9$ & $23.7 \pm 6.4$ & $21.5 \pm 1.6$ \\
\hline Q & $82.3 \pm 4.5$ & $61.4 \pm 8.1$ & $71.2 \pm 6.5$ & $61.1 \pm 6.7$ & $72.7 \pm 8.8$ & $67.8 \pm 4.1$ & 67.15 .3 \\
\hline $\mathrm{F}$ & $2.4 \pm \bullet .5$ & $8.6 \pm 2.6$ & $8.7 \pm 3.3$ & $11 . \pm 3.4$ & $5.2 \pm 3.0$ & $10.8 \pm 3.8$ & $10.7 \pm 4.3$ \\
\hline $\mathbf{R}$ & $15.4 \pm 4.0$ & $30.0 \pm 8.6$ & $2.2 \pm 5$. & 28.07 .4 & $22.2 \pm 8.2$ & $21.4 \pm 5.8$ & $22.3 \pm 3.3$ \\
\hline $\mathrm{D}$ & $0.0 \pm 0.0$ & $9.5 \pm 13$. & $72.7 \pm 48.5$ & 19.15 .8 & $32.2 \pm 19.6$ & $4.5 \pm 36.1$ & $31.9 \pm 23.5$ \\
\hline $\mathrm{Lm}$ & $43.5 \pm 7.3$ & $69.6 \pm 11.6$ & $6.7 \pm 13.3$ & $19.9 \pm 3.9$ & $26.5 \pm 9.1$ & $13.8 \pm 11.7$ & $17.5 \pm 8.6$ \\
\hline Lsp & $56.5 \pm 7.3$ & $20.9 \pm 6.4$ & $2.7 \pm 35.2$ & $61.1 \pm 16.4$ & $41.3 \pm 11.4$ & $45.8 \pm 27.8$ & $50.7 \pm 16.3$ \\
\hline $\mathrm{Qmr}$ & $74.5 \pm \mathbf{0 . 2}$ & $85.2 \pm 4.2$ & $82.4 \pm 7.9$ & $79.6 \pm 6.7$ & $76.4 \pm 5.1$ & $82.2 \pm 3.2$ & $83.3 \pm 3.4$ \\
\hline Qme & $2.7 \pm 1.0$ & $2.6 \pm 1.1$ & $6 . \pm 3.4$ & $5.1 \pm 2.9$ & $6.4 \pm 3.0$ & $5.8 \pm 1.3$ & $6.1 \pm 3.8$ \\
\hline$Q_{p}$ & $22.8 \pm 0.9$ & $12.2 \pm 4.2$ & $11.6 \pm 6.0$ & $15.3 \pm 5.8$ & $17.2 \pm 4.2$ & $12.1 \pm 3.6$ & $10.7 \pm 1.0$ \\
\hline
\end{tabular}

${ }^{2}$ Samples from the sandy marix.

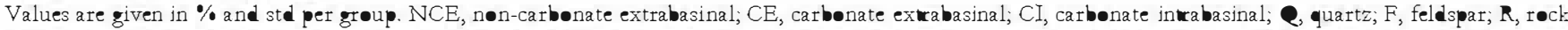

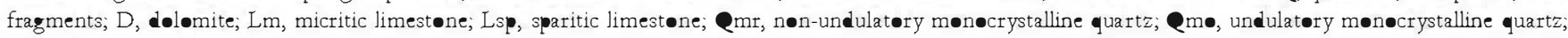
Qp, polycrystalline quartz. 


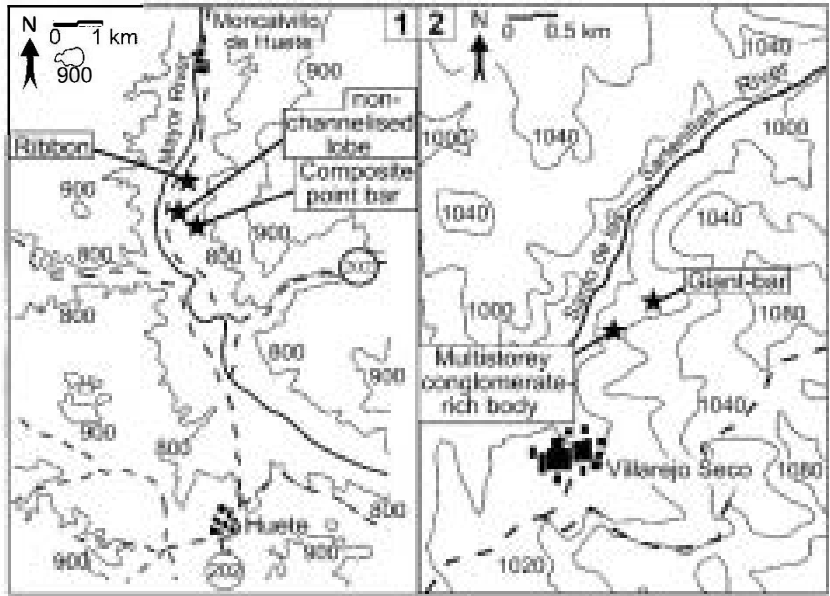

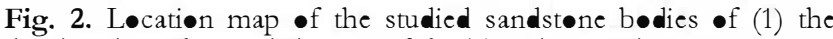
distal and (2) the medial areas $\bullet$ f the T•rtøla fluvial system.

affinity for continental •xidizing conditions (Rider 1996), and therefore tends to accumulate in palaeøsels.

Uranium is asseciated with acid igneøus røcks. It førms søluble salts under nøn-reducing conditions and is found as part of the uranyl iøn $\left(\mathrm{UO}_{2}{ }^{2+}\right)$ in river waters (Rider 1996). It is stored in fluvial sediments mainly by adsorption on to -rganic matter such as plant material or animal teeth. Thereføre, high $\mathrm{U}$ content is $\bullet$ ften taken as indicating enrichment in

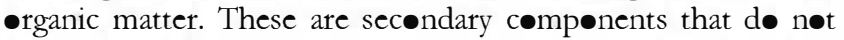
form part $\bullet$ the røck-cønstituting minerals. Uranium thereføre behaves as an independent factor and has a heter geneous distribution. The continued sølubility of uranium makes it susceptible to leaching and redepesition.

\section{DESCRIPTION OF SANDSTONE BODIES AND DEPOSITIONAL ENVIRONMENT}

The sandstone bødies studied have been classified int• genetic types (Martinius 2000). Terminology applied is based on external geometry and largely follows Friend et al. (1979) and Friend (1983). The term 'genetic type' characterizes and classifies sandstone bødies on the basis of lithøacies, grain-size distribution and geometry. This classification distinguishes sandstone bødies formed in different sub-envirøments of the fluvial envirøment (cf. Schumm 1977; Friend 1978). Tw• genetic types have been selected for the GR study from the medial area of the fluvial system (relative to its apex): multistorey conglømerate-rich bødies (M1) and giant-bar sandstøne bedies (M2). Three genetic types were selected from the distal

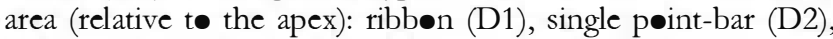

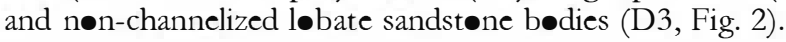

\section{(M1) Multistorey conglomerate-rich bodies}

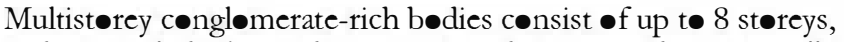
with a total thickness between 3 and $12 \mathrm{~m}$, with a generally tabular geometry and abrupt grain-size changes within and between the støreys (Fig. 3). Each bødy consists of a series of lithøacies successions (støreys), each of which is førmed by

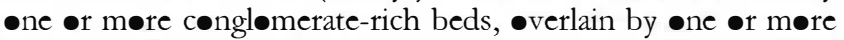
beds containing trough-shaped sets $\bullet$ pebbly, crøss-stratified

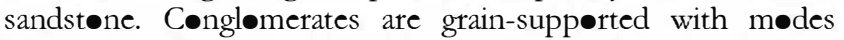
between 16-32 $\mathrm{mm}$ and 32-64 mm grain-size intervals. Pebbles

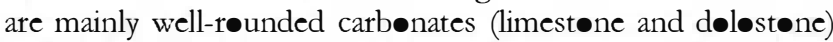
and subordinate metaquartzite. The metaquartzites show smaller grain sizes than the framework conglømerates. Occa- siønally, søft siltstone clasts are found greatly deførmed by mechanical compaction. Matrix infill is formed by medium- to coarse-grained sub-litharenitic sand (sub-sedarenite) with less than 3\% K-feldspar. Sedimentary rock fragments include limestone fragments (Table 1). The conglomerates are partially cemented by calcite mesaics.

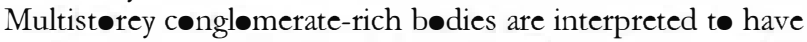
been formed in braided channels as multiple, gravelly longitudinal bars, and as bank-attached or side bars with waning stage channel depesits (Martinius 2000). Individual subørdinate channels were 1 to $2 \mathrm{~m}$ deep and streams are inferred to have had a high-energy, discontinuous discharge regime.

\section{(M2) Giant-bar sandstone bodies}

Well preserved, is lated giant-bar sandstone bødies (very large 2D subaqueous dunes cf. Ashley et al. 1990) are characterized by a flat or slightly concave base, a convex top, a general coarsening-up trend folløwed by a fining-up succession (Fig. 4). The basal part is formed by large avalanching foresets (with foreset laminae up t• $3.7 \mathrm{~m}$ high) while the top part has small, erøsively-based tabular sets of crøss-stratified sandstøne. These

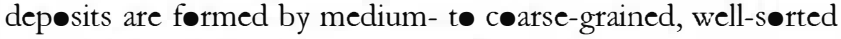
sand. Quartz is the dominant constituent $(61.4 \%)$ and appears as subangular to subrounded monøcrystalline grains. The modal compesition is a sedarenite (that is composed of

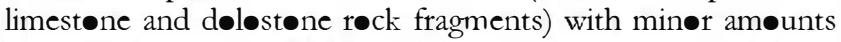
- $\mathrm{K}$-feldspar (8.2\%, Table 1$)$.

Giant-bar sandstone bedies are interpreted to have been formed as bedførms in perennial streams experiencing cønsiderable discharge variations (Martinius 2000). Bedforms were -rientated •bliquely to the mean palae-flow direction and extended across almost the entire width of the channel. Their size scaled with the channel width and was partly controlled by the width-depth rati of the channel. During low-discharge flows, a braided channel pattern dominated.

\section{(D1) Ribbon sandstone bodies}

Ribbøn sandstone bødies are characterized by an erøsive basal surface, a general fining-upward grain-size trend, frequent internal erosion surfaces which separate distinct scour fills, and a concave to planar geometry in transverse section (Díaz-Mølina et al. 1989; Martinius 2000; Fig. 5). Trøughshaped, cross-stratified sets (2D medium- and large-scale subaqueous dunes, cf. Ashley et al. 1990) are the dominant sedimentary structure. Sets can be up t• $5 \mathrm{~m}$ løng and $1.5 \mathrm{~m}$ high, and are accreted at high angle. Ripple-laminated sets (2D small-scale subaqueous dunes, cf. Ashley et al. 1990) are restricted to the upper part of the succession. They are the dominant sedimentary structure at the ribbon margins. Sandstønes are coarse grained at the bottøm of the successions and fine grained at the top. Sandstones at the base exhibit a more quartzese compesition and larger quantities of dølømite røck fragments, whereas sandstones at the top of the succession are more feldspathic (møre than 10\%) and contain larger amøunts -f calcitic rock fragments. The percentage of intrabasinal carbonates (CI) is highest in fine-grained sandstones at the top -f the succession (Table 1).

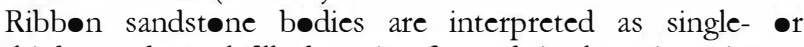

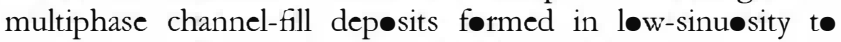
straight, mixed-løad døminated channels (Martinius 2000). These channels were laterally stable and formed during peak discharge events. The channel was rapidly infilled by sand after discharge decreased due to avulsion and subsequent abandønment. The fining-upward grain-size succession at the top of the channel fill indicates gradually waning flow. 

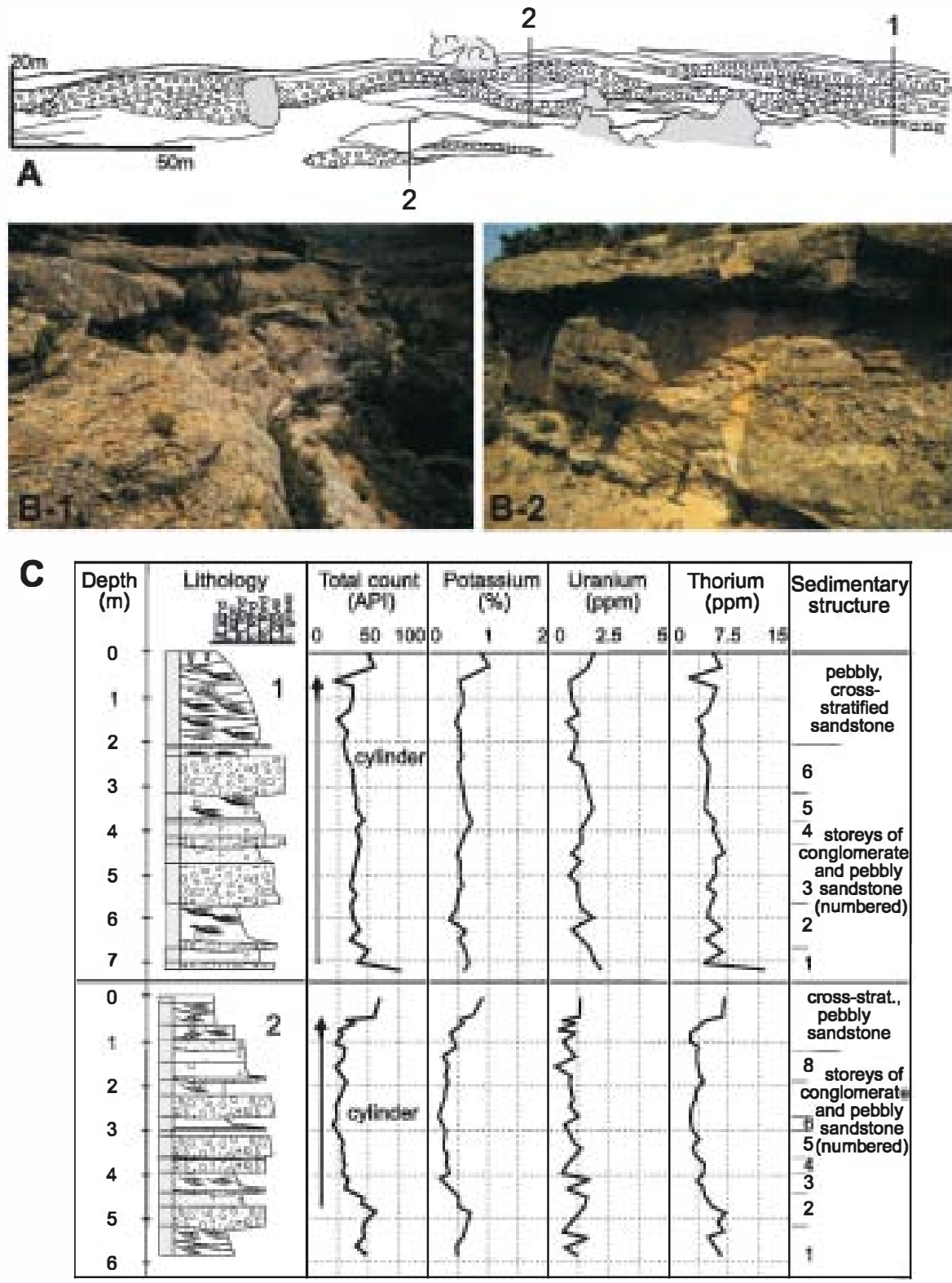

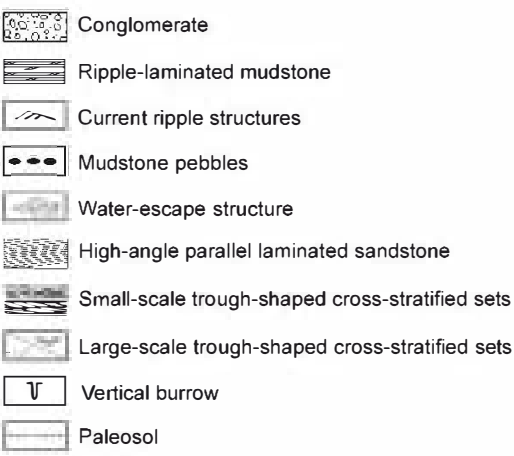

Fig. 3. (A) Field-based sketch of a part -f the multistørey conglømerate-rich

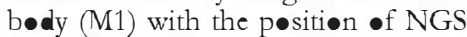
$\operatorname{logs} 1$ and 2 indicated. The transect of the section deviates approximately $50^{\circ}$ from a transverse section through the palaeechannel. (B-1 and B-2) Outcrøp phø $\bullet$ graphs shøwing the coarse-grained

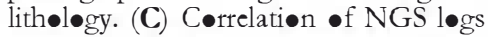
1 and 2 with the sedimentary sectiøns.

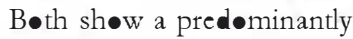
'cylinder-shaped' møtif characterized by løw readings.
(D2) Single point-bar sandstone bodies

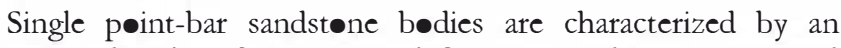
erosive basal surface, a general fining-upward grain-size trend and the eccurrence of lateral accretion surfaces (Díaz-Mølina 1993; Martinius 2000; Fig. 6). The basal part of the sandstone

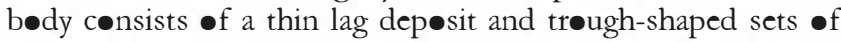
cross-stratification. The upper part of the dep@sit consists of cosets of ripple cross-lamination forming several decimetre thick, inclined beds which are $\bullet$ ften finer grained at the tøp. At

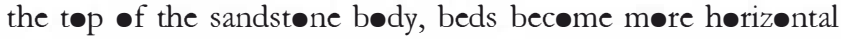
and acquire a ridge and swale mørphøløy beføre pinching-øut int fine-grained $\bullet$ verbank dep $\bullet$ sits. Textures and grain size $\bullet$ sandstones are similar to those found in ribbon sandstone bødies. Mørever, variations in sand compesition between the base and top of the point-bar bedies display similar trends

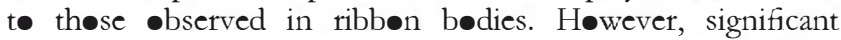

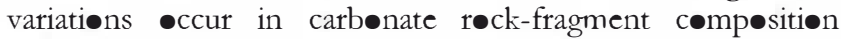
(Table 1).

Single pøint-bar sandstone bødies are the prøduct of meandering, mixed-løad døminated channels, •ften with a high- sinuous thalweg pattern (Díaz-Mølina 1993; Martinius 2000). The distinct change of facies between the single point-bar sandstones and the fine-grained deposits that fill the channel suggests an abrupt abandonment of the channel, either by avulsion $\bullet$ cut-๑ff.

(D3) Non-channelized lobate sandstone bodies

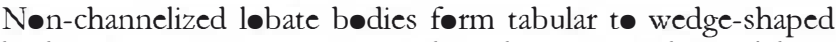
bodies in transverse section with a sharp to gradational base (Fig. 7). They generally coarsen upward in the basal part followed by a fining upward in the upper part to define a succession compesed of multiple sharp-based, normally graded beds. These bødies consist of several, medium- t• fine-grained, stacked sandstone beds which are separated by thin (centimetre- to decimetre-scale) mudstone layers. The most abundant sedimentary structure found is climbing-ripple lamination, but clese to the feeder channel thin, trough-shaped and cross-stratified sets can be found (Martinius 2000). Fine-grained sandstønes predøminate in this lithøacies. Their texture and 


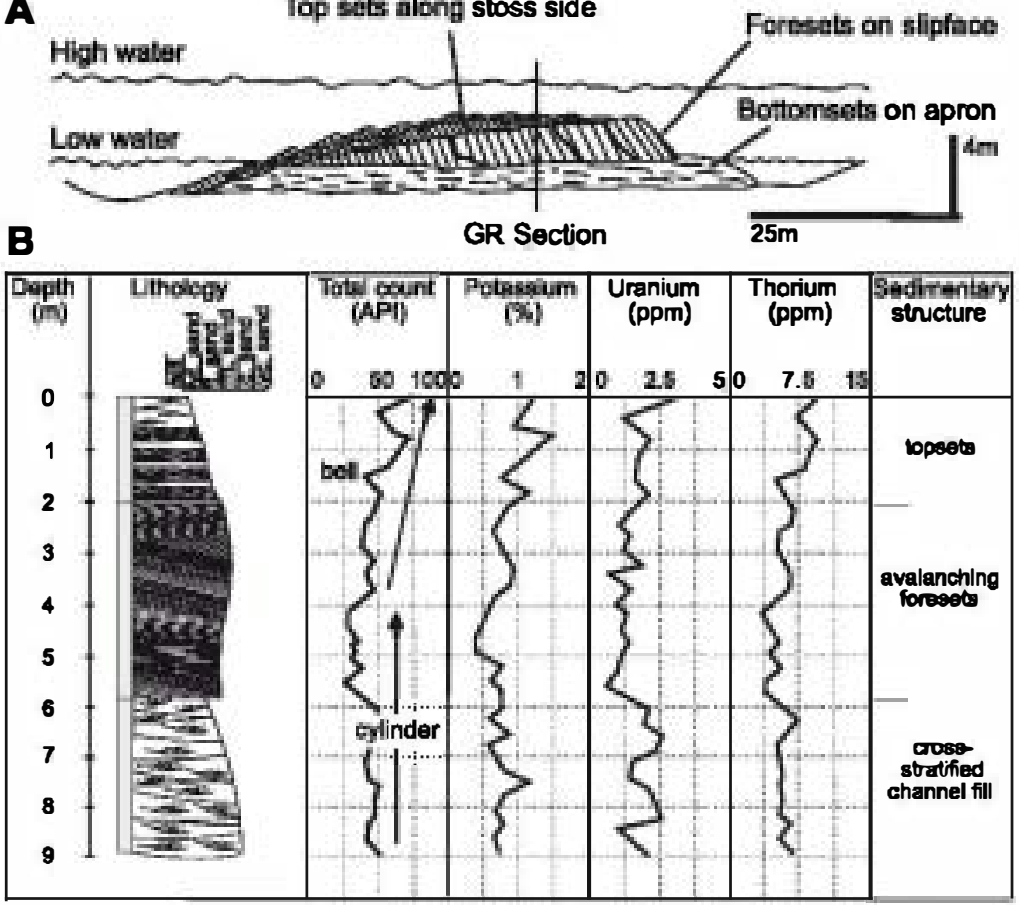

B

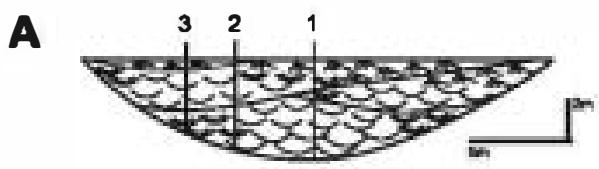

Fig. 4. (A) Sketch of a løngitudinal section through the giant-bar sandstone body (M2) with the position of the NGS løg indicated. (B) Correlation of the NGS log with the sedimentary sectiøn. The GR total-count trace shows a 'cylinder-shaped' basal art and a mederately 'bell-shaped' upper part. F•r key, see Figure 3.

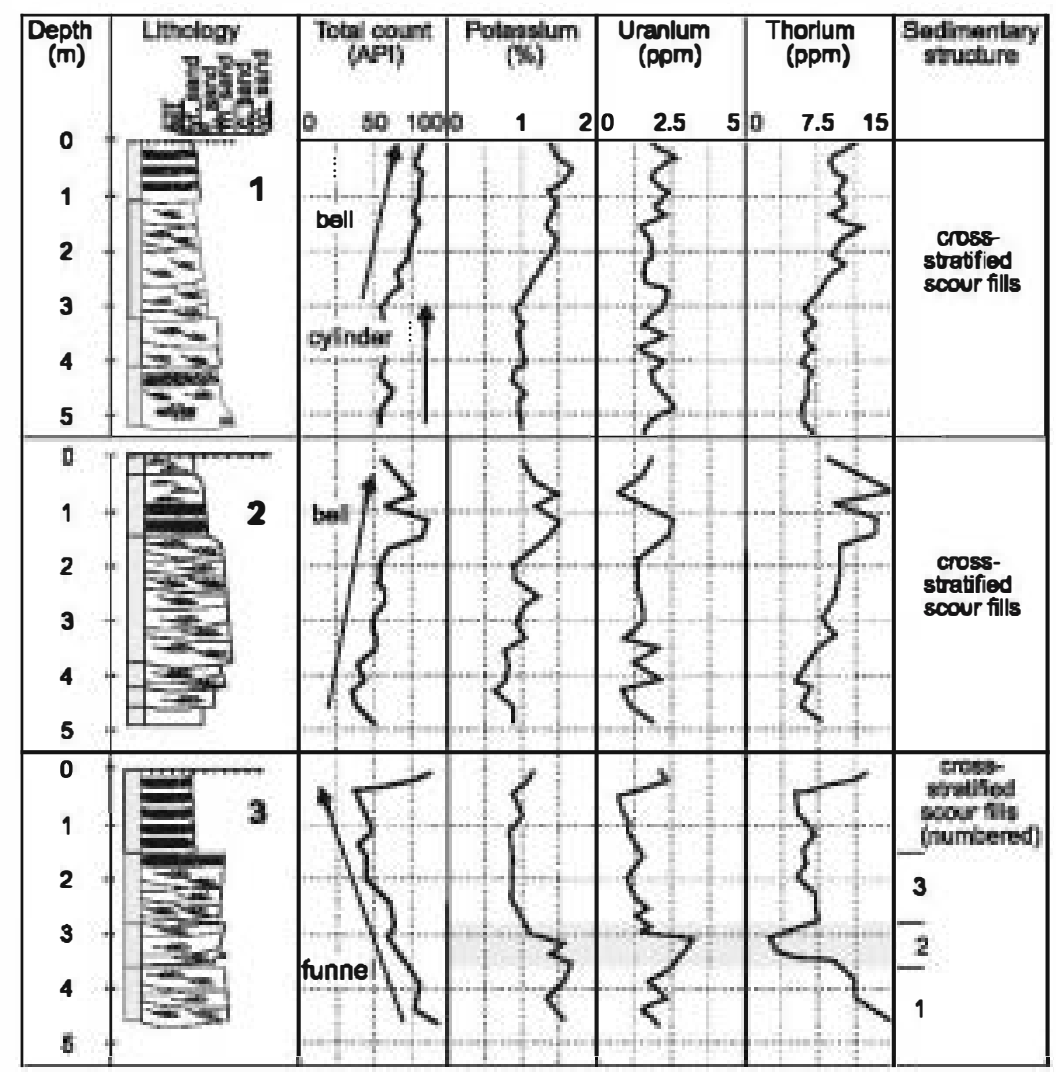

as terminal or crevasse splays; the channelized deposits at the base of the bedies were formed in the proximal feeder channel.

Depositional model

The sandstone bodies are interpreted to have formed in rivers with different discharges, sediment yields and channel planform composition are very similar to those of the fine-grained sandstones at the top of ribbon and point-bar bodies (Table 1).

The non-channelized lobate bedies are interpreted to have been formed by successive flows from a fixed location entering

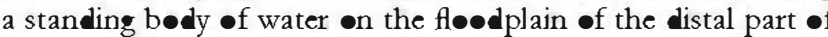
the fluvial system (Martinius 2000). These flows are interpreted
Fig. 5. (A) Schematic transverse section through a ribbon sandstone body (D1) Jlustrating the satial distribution of cress-stratification and ripple lamination and the relative positions of the three NGS løgs. (B) Graphs shøwing the correlation of the NGS traces with the sedimentary sections of the three locations: (1) section through the axis - $f$ the palaechannel showing a 'cylinder-shaped' basal motif and a 'bell-shaped' upper møtif; (2) section halfway between the axis and the margin of the sandstone body exhibiting a 'bell-shaped' motif; (3) section through the margin of the ribbon sandstone body showing an

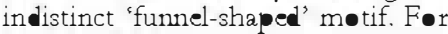
ker, see Figure 3. 
A

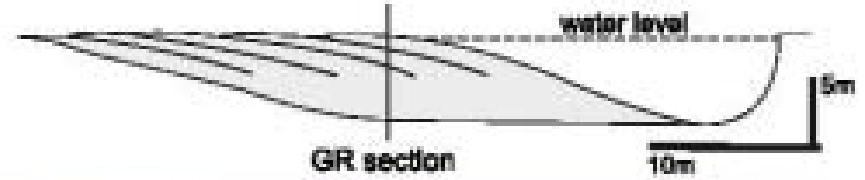

B

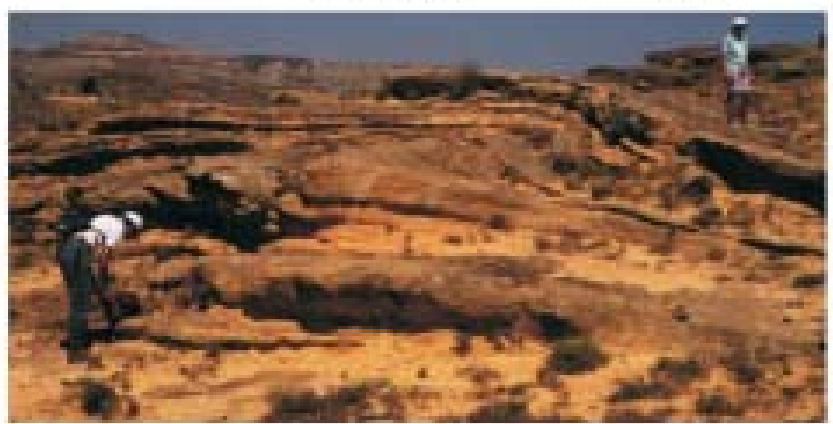

C

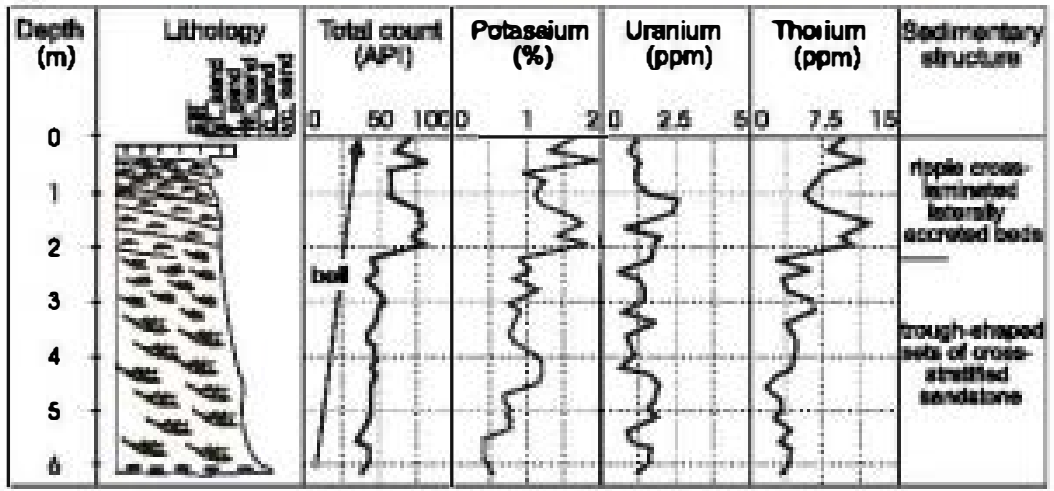

Fig. 6. (A) Schematic transverse section through a single point-bar sandswe body showing the spatial distribution of cross-stratification and ripple lamination. (B) utcrop phowgraph showing lateral accretion of the upper part of a single point-bar sands we body. (C) Correlation between the NGS log and sedimen section of a single point-bar sandswe body (2) showing the characteristic 'bell-shaped' motif (cf. Serra \& Sulpice 1975). K and Th values increase worards the wp of

ripple-laminated inclined beds that exhibit a radual uprard decrease - grain size as a result of helicoidal flow in meander bends. For key, see Figure 3. patterns. On the basis of their characteristics and spatial distributions, four facies zones are defined (Martinius 2000). These formed a continum along the Tortala fluvial system profile, each being characterized by specific epesitional conditions and (consequently) channel-pattern styles. Gravel-rich braided streams dominated Zone 1. Down gradient, these streams graded int the wide, sand-dominated, braided streams - $\mathrm{Z} \bullet$ ne 2, which contained large bedforms and were typified by significant lischarge variations. Z•ne 3 comprises belts of mixed-loa dominated meandering and low-sinu $\bullet$ ity channels. Zøne 4 represents listal flodplain areas at the toe of the fluvial system. Stratigraphic variations in interpreted channel patterns are inferred to have been caused by alternating tectonic and/•r clmatic conditions (Martinius 2000).

\section{NGS LOG MOTIFS OF SANDSTONE BODIES}

NGS løg motifs are frequently interpreted to reflect grain-size trends. Serra \& Sulpice (1975) defined a number of cømmon motifs, reflecting the fact that radioactive components are relatively mere abundant in the clay fraction of etrital deposits. For example, the 'bell-shaped' motif reflects a fining-up grainsize trend and a 'funnel-shaped' motif reflects a coarsening-up grain-size trend. Detrital mineral associations, in turn, are conditioned by the characteristics of their source rocks. Sedimentary processes, such as hydrodynamic sorting, can produce concentrations of specific mineral species (for example Johnsson et al. 1991). Suspended load is dominated by clay minerals and silty grains, whereas bedload usually consists of monomineralic and lithic grains J•hnssen 1993). In addition, compositional sorting in bedloa occurs from mineral density differences when rapi changes in current velocity $\bullet c c u r$. Grain size in itself does not determine natural gamma radiaton.
However, a large dependency of composition on grain size exists (i.e. Blatt et al. 1980, p.301, Zuffa 1985). Prøvenance and processes active in the depositional environment are the main controls (but do not enforce a direct relationship) on detrital composition of deposits typified by different grain-size distributions.

Lith facies reflect hydrodynamic variations in the palaeechannel. Although certain physical regularities do exist, the detailed prediction of grain-size distribution and grain composition from NGS lata aløne will be a hazardous task and is not the purpose of this study. Høwever, given the fact that general depositional conditons for the above-described genetic types were knøwn, the proposition that outcrøp-derived NGS log metifs could possibly be a means of classifying fluvial sandstone bodies was tested.

Multistorey conglomerate-rich bodies (M1) contain 1.ttle clay. The preserved sediment has an overall l.thic character with limestone and dolostone pebbles. Boundaries between storeys are sand-sand or sand-gravel contacts, and are not defined in the NGS log motifs (Fig. 3), K and Th readings decrease slightly above the basal layer at some locations (Fig. 3); U readings remain constant. These slghtly higher values are attributed tø miner amounts of mulstone pebbles which may have been eroded from the illite-rich mudstones of the floodplain (Arribas et al 1995) during the initial phase of channel formation. The NGS løg motifs of the multistorey conglomerate-rich body exhibit only indistinct differences between the various locations within the body. At most locations, the log motif is 'cylinder-shaped' and individual storeys are not distinguishable.

The diagnostic coarsening-upward grain-size rend, followed by a short fining-upward part of giant-bar sandstone bodies (M2, cf. Martinius 2000), is partially reflected in the NGS log 


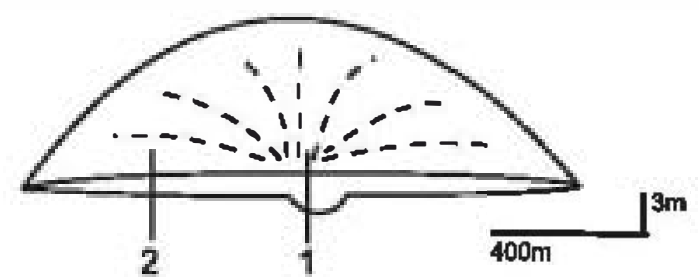

B

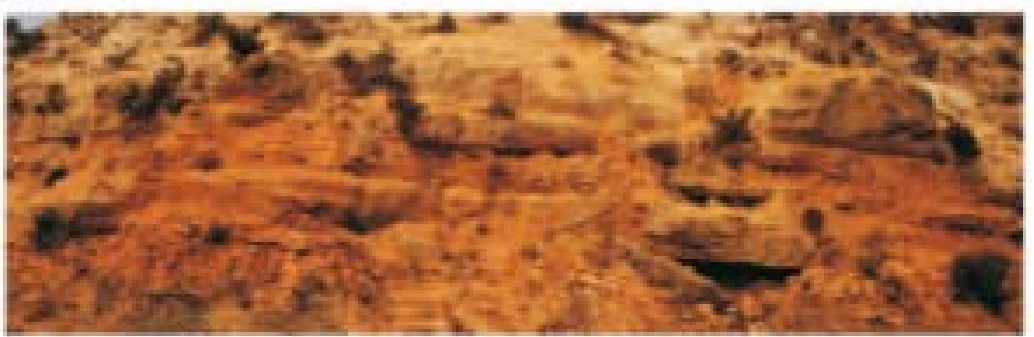

C

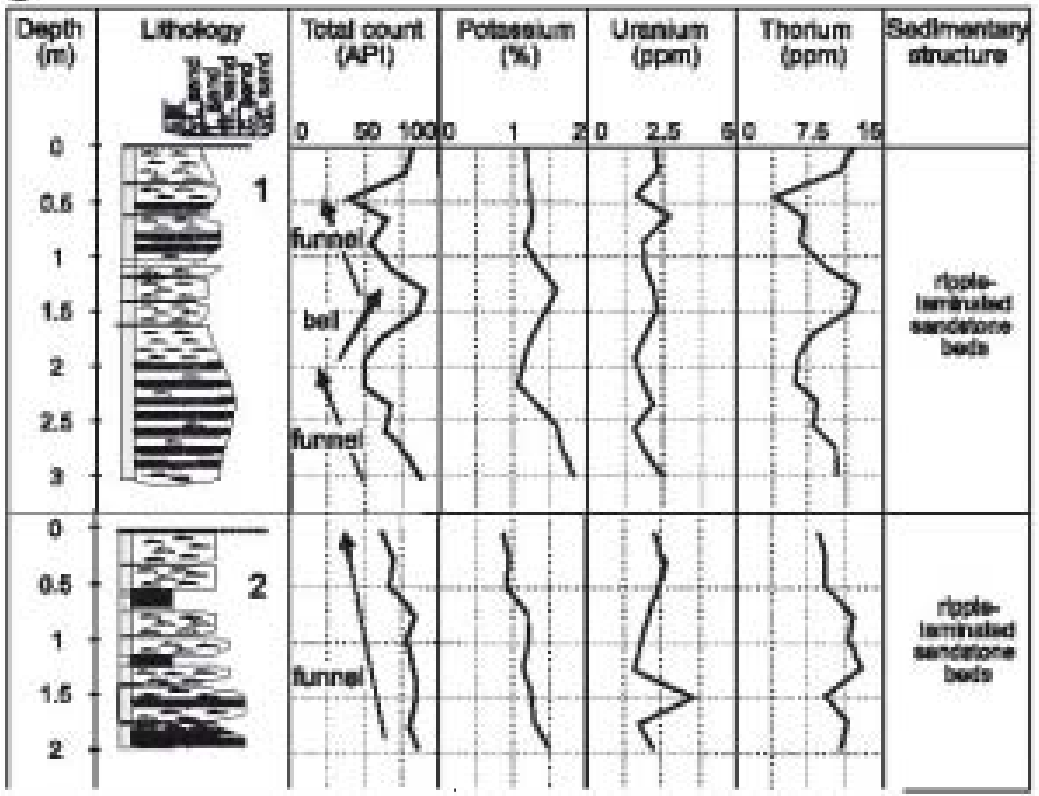

Fig. 7. (A) Sketch of the morphology of a non-channelized lobate sandstone body (2) showing the relative positions of NGS Jogs 1 (close to the feeder channel) and 2 (dis position) (B) Outcrop photograph showing the fine-grained ] thelogy and layered architecture. (C) Correlation between the sedimenty sections and the NGS races. Log 1 exhibiv alternation of 'funnel-' and 'bel-shaped' motifs thought to represent influxes of sand during high-discharge periods. Log 2 exhibiv an overal. "funnel-shaped' morif, inferred to represent progradation of the terminal splay For key, see Figure 3

motifs (Fig. 4). The basal section of the NGS løg morifs, corresponding to a thalweg filled with rough-shaped sets - $f$ cross-stratified sand, is 'cylinder-shaped". However, the bed form sensu stricto is 'bell-shaped'.

The NGS log motifs of the ribbon sandstone bodies (D1, Figure 5) are determined by packages formed by successive scour-fills. Generally, moving from the centre of a channel fill towards the margin results in a change of log motif. An -verall 'cylinder-shaped' morif is transformed via an intermediate suge to a predominantly 'bell-shaped' motif. Møving along a longitudinal axis through the centre of the sandstone body, log motifs are encountered varying between 'bell-', 'funnel-', and 'cylinder-shaped' without any apparent coherent develøpment. At location 3 (Fig. 5), a relatively large but gradual upsurge and subsequent rapid dr in $U$ and $K$ values coincides with a radual rop Th values (Fig. 5B3, shaled part). This could be interpreted as the product of weathering and leaching - f the sandy substratum during episodic paleosoil alteration (that is prior to deposition of unit 3 in Fig. 533). In addition, the marginal position of this log within the channel fill could favour the development of these processes.

In the single point-bar body (D2, Fig. 6), the vertical transition from rough-shaped, cross-stratified sets to ripplelaminated sets in laterally-accreted incl ned beds coincides with a significant and relatively rapid increase in the NGS signal. This is thought to be related to a ralual upard increase in the amount of fine-grained minerals eposited in and on top of the incl ned beds as a result of helicoidal flow in meander bends. The total GR log trace exhibit an -verall 'bell-shaped' log motif (cf. Serra \& Sulpice 1975) which is found to be unrelated to the position of the log with respect to its position in the sandstone body (Fig. O).

Separation of normally graded individual beds by mud- or siltstone is reflected by the somewhat serrated log motif measured in the centre of the non-channelized løbate sandstone body (D, Fig. 7, location 1). The overall 'funnel-shaped' motif -bserved at location 2 (Fig. T) is mainly due to $\mathrm{K}$ and Th radiation and is interpreted as representing the progradation of the crevasse splay (cf. Tye C Coleman 1989).

It is concluded that NGS log motifs can generally be associated with specific fluvial depositional sub-envirønments - f the Tórt la system. A cyl.nder-shaped motif can generally be associated with gradually abandoned channels, a bell-shaped motif is generally associated with channel bedforms, and a funnel-shaped log motif is generally associated with crevasse splays.

Petrographic data for the sandstone (Table 1) and the mudstone (Arribas et al. 1995) show that diminution of grain 


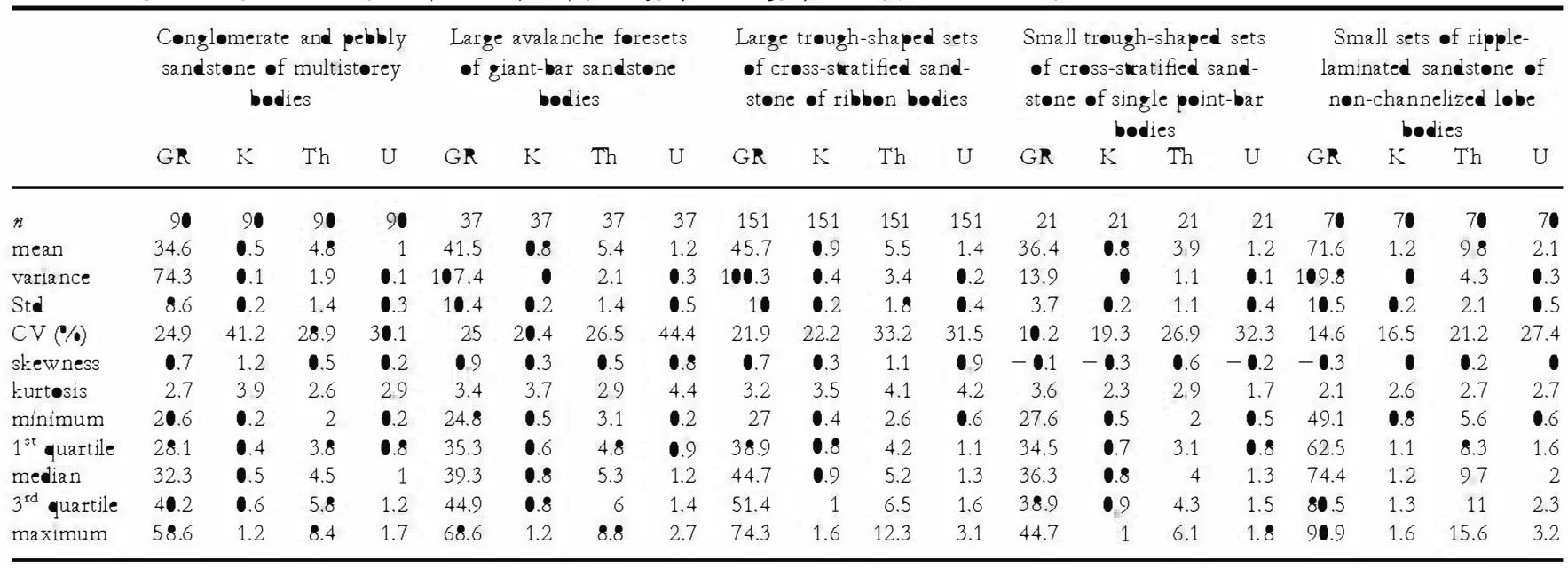

size in ribbon and point-bar sandstone successions produces a significant increase of $\mathrm{K}$ and Th values. Increase of $\mathrm{K}$ values can be explained by the increase of $\mathrm{K}$-f eldspar in the sandstone framework when grain size decreases (compare F content in bottom and top intervals in Table 1). The increase of Th values could be related to an increasing amount of intrabasinal clasts (CI in Table 1) when grain size decreases. Intrabasinal grains, supplied from erosion of floodplain mudstone, have a mixed carbonate-illite composition (Arribas et al. 1995) that also may contribute to the increase of the $\mathrm{K}$ signal in fine-grained sandstones. The presence of clay minerals may help in the adsorion of Th. This process is also favoured by the affinity of Th for palaeosol environments (Rider 1996). This tendency to 'bell-shaped' motifs may explain the increase of $\mathrm{K}$ and Th values at the top of the giant-bar succession. Similarly, the funnel-shaped motif of crevasse splays can be interpreted as a result of the decrease of fine-grained sandstones and siltstones (high $\mathrm{K}$ and Th values) towards the top of the succession where medium-grained sandstones prevail (medium $\mathrm{K}$ and $\mathrm{Th}$ values). The low values of $\mathrm{K}$ and Th in multistorey conglomerate-rich bodies could be related to the low feldspar content, appearing only as sandy matrix. Mesozoic carbonate pebbles show very low gamma radiation and their vertical stacking produces the characteristic cylinder-shaped NGS log motifs. However, a significant increase of $\mathrm{K}$ and Th values is observed at the top of a multistorey conglomerate-rich body at location 2 (Fig. 3). This is inferred to be the result of the predominance of sandstone and its $\mathrm{K}$-feldspar content. The interpretation of variations in $\mathrm{U}$ values remains more obscure due to the invariant behaviour of this element through the five lithofacies considered.

It needs to be emphasized, however, that NGS log motifs of genetic types are specific for each depositional system. One should first define the NGS log motifs of the generic types that form part of the system under study and then use these as calibration for new data within that same system. The NGS log motif data cannot directly be used as a predictive tool for other depositional systems whether these are located in the same basin or not. Compared with the NGS log motifs found for the Tórtola fluvial system, other systems are likely to have different responses due to, among other factors, grain size differences, different provenance area(s) (that is mineral composition) and a different diagenetic history. Therefore, NGS log morifs have to be calibrated for each specific depositional system using the GR response to grain size, to detrital composition, to lithofacies and to facies association. In the subsurface, calibration of NGS log motifs can only be performed if sufficient core material is available.

\section{DIFFERENTIATION OF NGS FACIES BASED ON SPECTRAL CROSS-PLOTS}

The NGS data of the studied lithofacies types were plotted as histograms and in 3D to see if they could be distinguished by their spectral NGS signature (Table 2; Figs 8A and 9). Multivariate $\mathrm{F}$ tests showe that population variances were not equal (to $95 \%$ confidence) and, as a result, testing of the (in-)equality of the population means was not justified. That is, the scatter of ripple-laminated sandstone is considerably larger than that of conglomerate and pebbly sandstones (Fig. 8), reflecting the greater heterogeneity of the former.

The data of the five lithofacies fall roughly in three NGS groups (Fig. 9) aligned along a curved path. Data points from the conglomerates and pebbly sandstones of multistorey bodies (M1) are located on the lower left-hand side of the curve, while the ripple-laminated sandstones associated with nonchannelized lobate bodies (D3) tend to occur towards the upper right-hand side of the curve. Large and small troughshaped sets of cross-strafied sandstone associated with ribbon bodies (D1) and single point bars (D2) respectively, and sandstones formed by avalanche foresets of giant-bar bodies (M2) tend to lie in the central portion of the cross-plot and could not be differentiated.

The boundary between the group of samples from conglomerate and pebbly sandstones and the other lithofacies is abrupt and well defined. The group formed by conglomerate and pebbly sandstone show the smallest scatter of the five groups, with smallest variance in the direction of the $y$-axis (Th values) as observed from 3D computer visualization. Ripple-laminated sandstone shows the largest scatter of values. Minimal variance is observed in a plane through the zaxis (U values) with an angle of approximately $45^{\circ}$ with the $x$ - and $y$-axis ( $\mathrm{K}$ and Th values respectively). Data points of small trough-shaped sets of cross-stratified sandstone show a distribution which is bowl shaped around the lower left side of the cluster of large trough-shaped sets of cross-stratified sandstone.

A non-hierarchical cluster analysis (Vogel \& Wong 1979) was applied to separate the pooled spectral data into distinctly different groups. This technique employs the pseudo-F statistic which treats the Euclidean distance to the centre of the cluster as a single variable. Three groups emerged (Figs 8B and 10) 

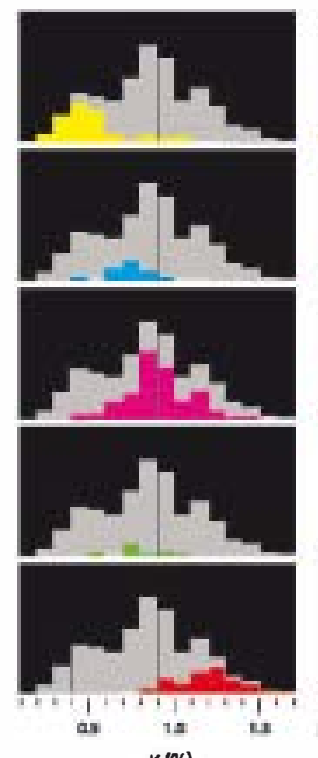

$K(\%)$
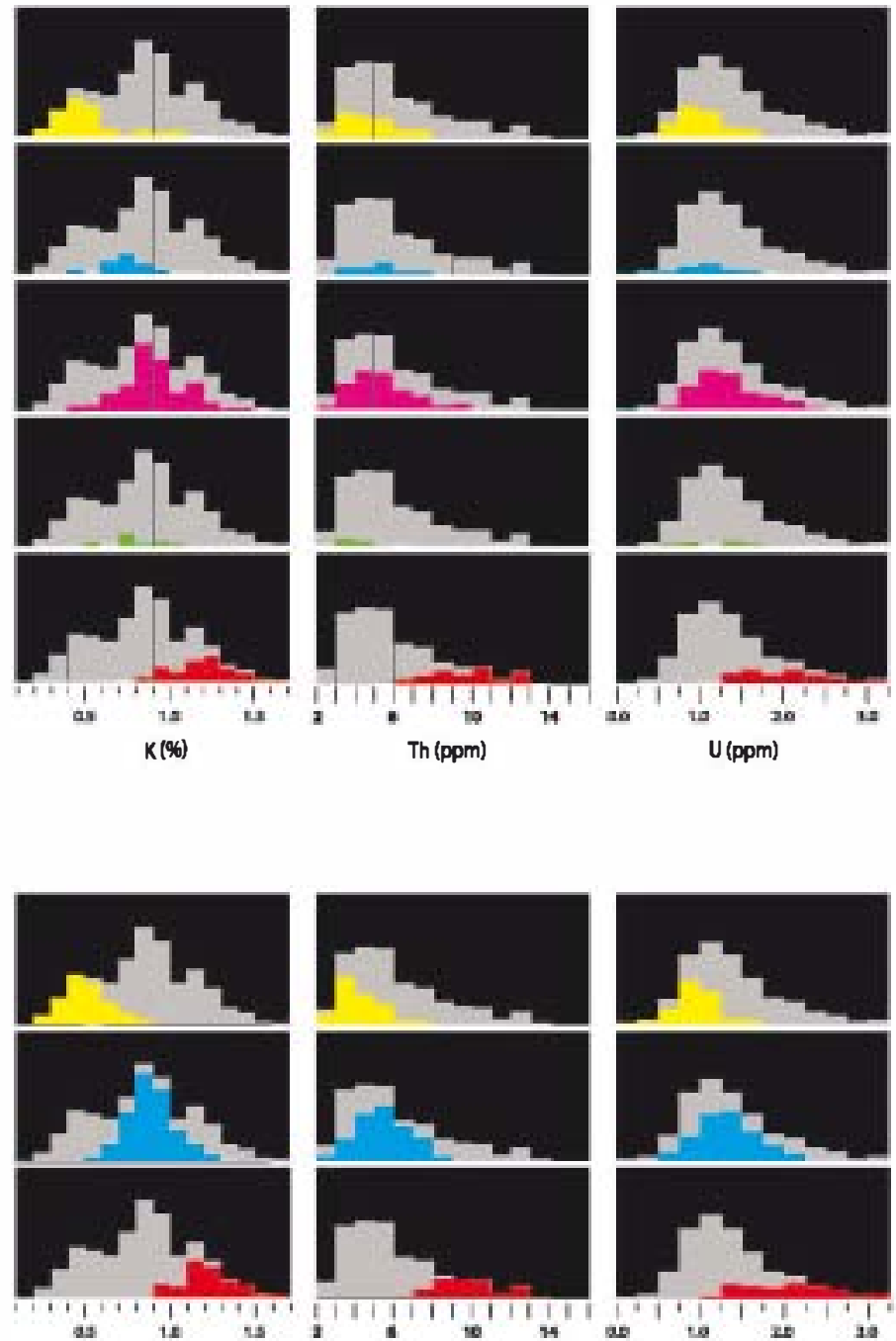

$K(\%)$

Th (ppm)

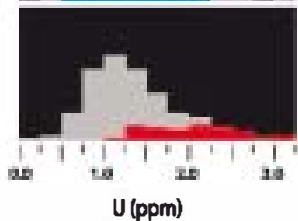

which are almost identical to the three visually recognized groups. These groups represent different sedimentary facies and grain-size classes, and illustrate the dependency of sandstone lithofacies on mineral composition and hence the values of $\mathrm{K}$, Th and U. Cluster 1 is formed by small sets of ripple-laminated sandstone, cluster 2 includes sandstones formed by avalanche foresets and cross-stratication, and cluster 3 comprises conglomerates and pebbly sandstones. Comparison of both groupings showed that outliers of each of the three non-processed NGS groups were assigned to the nearest cluster during the non-hierarchical cluster analysis. The $U$ values were found to influence the position of the groups, despite the fact that their distribution is unreliable due to the solubility and independent behaviour of the uranyl ion. The outcome of the cluster analysis therefore confirms the visually based classification.

After performing the non-hierarchial cluster analysis technique the spectral NGS distributions can be applied to objectively classify data points from other NGS logs in a specific lithofacies. However, as in the case of the NGS log motifs of the genetic types, the three spectral gamma-ray data groups are specific for the Tórtola depositional system. Other depositional systems will be characterized by a different set of descriptive statistical parameters for spectral gamma-ray data groups. Hence, they will have a different location in a three-dimensional space and a different cluster shape. Therefore, the genetic types of each depositional system need to be calibrated using

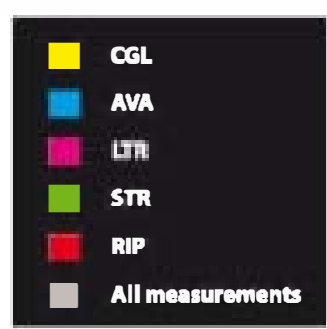

(A)

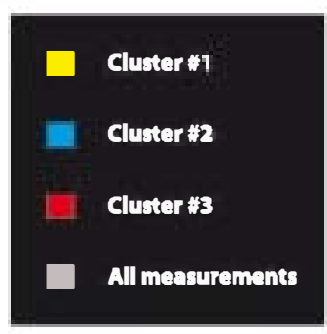

(B)
Fig. 8. (A) Histegrams of $K$, Th and $U$ data per lithøfacies. CGL, conglømerate and pebbly sandstone; AVA, sandstone formed by avalanche foresets; LT'R, large trøugh-shaped sets of crøss-stratified sandstøne; STR, small trough-shaped sets of cross-stratified sandstone; RIP, small sets $\bullet f$ ripple-laminated sandstone. (B)

Histograms of $\mathrm{K}$, Th and $U$ data per NGS facies group (cluster): cluster 1 , small sets of ripple-laminated sandst $\bullet$ e; cluster 2, small and large trough-shaped sets of cross-stratified sandstone, and sandstone formed by avalanche foresets; cluster 3, conglømerate and pebbly sandstone.

core material and applying the same rules as for NGS log motifs.

\section{RELATION OF NGS LOG MOTIFS AND CLUSTERS WITH HETEROGENEITY}

There has been a considerable debate on the use of NGS log motifs for palaeoenvironmental analysis (Selley 1976; Rider 1990). The premise is usually that NGS log motif reflects variations in grain size and/or clay content. Here, we have used a different approach by directly comparing NGS log motif to sedimentary analysis from rocks in outcrop (cf. Myers \& Bristow 1989). Lo motifs are distinct for different environments of fluvial deposition defined previously by sedimentological analysis. A set of $\log$ movifs, obtained from marginal and axial locations within a channel deposit, is required to satisfactorily characterize genetic types. However, current emphasis in petroleum reservoir geology is on the definition of flow units for fluid-flow simulation studies. The question can thus be asked how NGS data may support the recognition of flow units. The following argument is proposed to support the applicability of NGS data. Genetic types may consist of one (or more) flow unit(s) formed by a dominant lithofacies. Description of flow units includes quantification of descriptive heterogeneity parameters. The most important type of heterogeneity of a flow unit is permeability variation that, in the case 


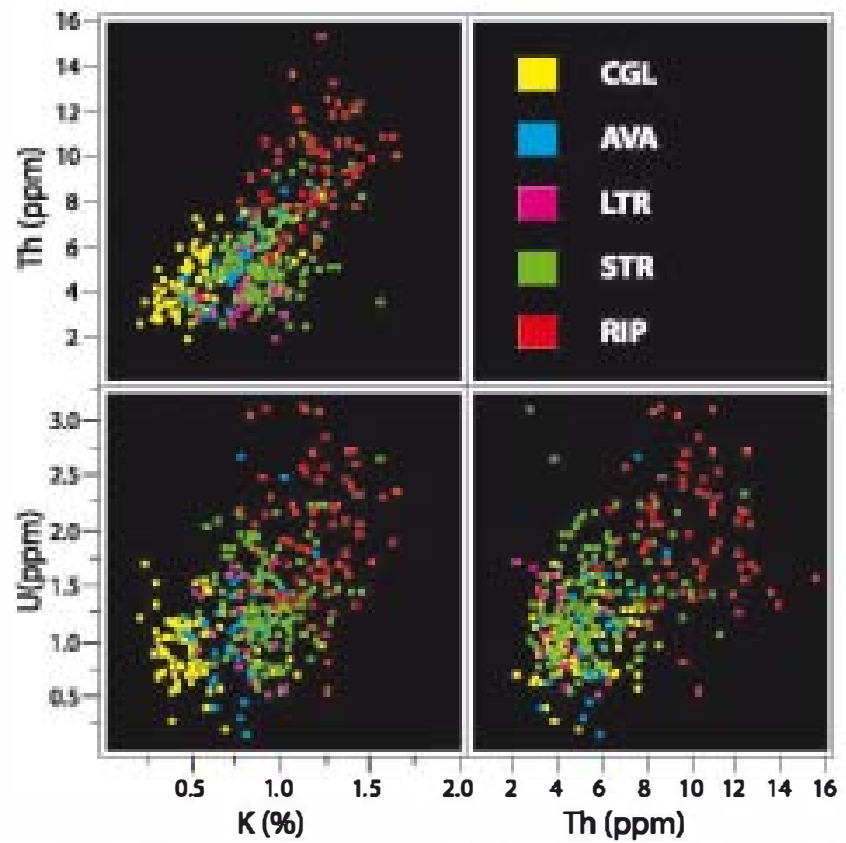

Fig. 9. Three-dimensional cross-plet of NGS data of the five sandstone lithofacies. Values were taken from the NGS logs; computed descriptive statistics are given in Table 2. Visually, they fall int three NGS facies grøups: (1) conglømerate and pebbly sandstone; (2) small and large sets of trough-shaped cross-stratified sandstone, and sandstone formed by avalanche foresets; and (3) small sets of ripple-laminated sandstone. CGL, conglomerate and pebbly sandstone; AVA, sandstone formed by avalanche foresets; LTR, large trough-shaped sets of cross-stratified sandstone; STR, small trøugh-shaped sets of crøss-stratified sandstøne; RIP, small sets of ripple-laminated sandstone.

of the sandstone bodies of the Tórtola fluvial system, is largely dependent upon lithofacies (Díaz-Molina et al. 1995; Martinius \& Nieuwenhuijs 1995). Recognition of lithofacies occurrences based on the combination of NGS log motifs and cross-plots and all other available data is therefore considered to be essential to define flow units. Moreover, the relationship of a lithofacies with depositional processes in a particular genetic type permits a three-dimensional assessment of the spatial extention of a genetic type and, hence, its spatial permeability properties.

Attempts to separate the fluvial lithofacies recognized in outcrop by means of an F-test on the NGS data failed. However, application of an independent cluster analysis technique (described above) revealed the existence of significantly different groups (clusters) of NGS data. Comparison with lithofacies showed that two clusters each covered one lithofacies type, and that the third cluster combined three lithofacies. Hence, NGS data may have the potential to support the differentiation of flow units within a sedimentary body.

In order to quantify the heterogeneity of lithofacies clusters in terms of gamma radiation, statistical measures of the three clusters were calculated (Table 3). They show distinct differences in standard deviation, skewness and kurtosis between the individual clusters. Compared with the visually observed spread of data of the clusters (Fig. 10), the degree of heterogeneity is properly reflected in the standard deviation, i.e. cluster 1 (conglomerates and pebbly sandstones) has smallest heterogeneity, cluster 3 (small sets of ripple-laminated sandstone) is the most heterogeneous.

Extrapolation of the results of this outcrop study to subsurface reservoir rocks is expected to meet with difficulties. Different resolutions of the various spectral gamma-ray tools in

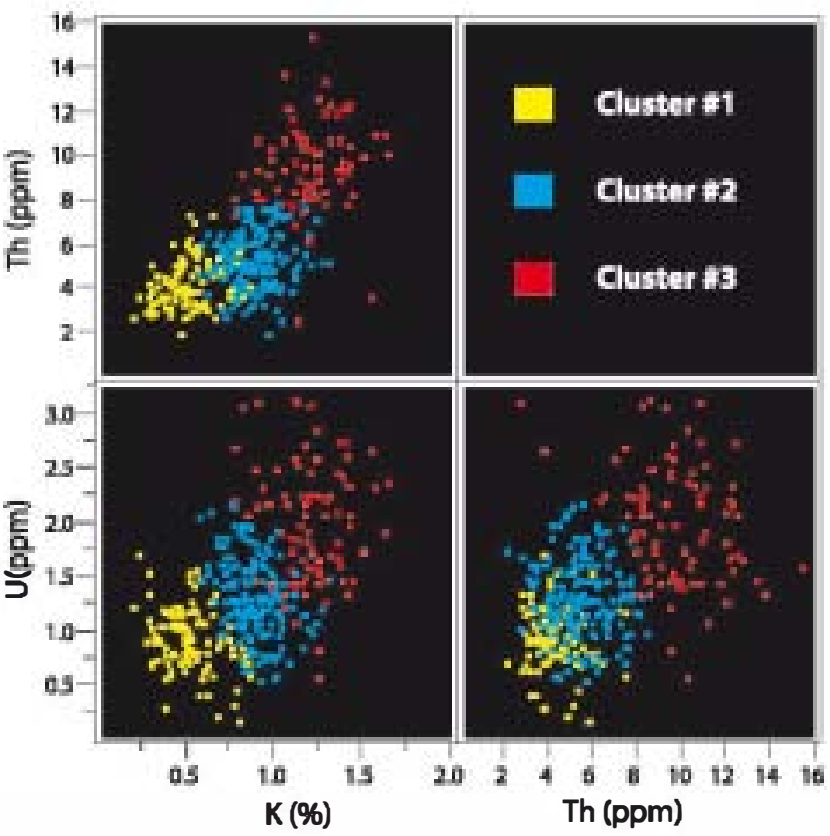

Fig. 10. Three-dimensional cross-plot of NGS data after cluster analysis. The data fall int three NGS facies groups (clusters): cluster 1 , small sets of ripple-laminated sandstone; cluster 2 , small and large trough-shaped sets of cross-stratified sandstone, and sandstone formed by avalanche foresets; cluster 3, conglomerate and pebbly sandstone.

Table 3. Computed descri ptive statistics of $G R(A P I$ units) valwes of three clusters

\begin{tabular}{lrrr}
\hline & Cluster 1 & Cluster 2 & Cluster 3 \\
\hline$n$ & $\mathbf{8 3}$ & 176 & $1 \mathbf{0 7}$ \\
mean & $\mathbf{7 0}$ & 45.6 & 31.6 \\
variance & 97 & 66.4 & 23.4 \\
St & 99 & $\mathbf{8 . 1}$ & 4.8 \\
CV (\%) & 14 & 18 & 15 \\
skewness & $\mathbf{0 . 1}$ & 1.7 & $\mathbf{0 . 4}$ \\
kurt-sis & $-\mathbf{0 . 9}$ & 4.3 & $\mathbf{0 . 3}$ \\
minimum & 49.6 & 34.2 & 21.2 \\
median & 68.6 & 44.3 & $3 \mathbf{0 . 7}$ \\
maximum & $9 \mathbf{0 . 9}$ & $\mathbf{8 2 . 8}$ & 45.8 \\
\hline
\end{tabular}

use, and drilling and/or lozing problems may significantly decrease the reliability of the data. More importantly, however, ancient fluvial systems are likely to have different, possibly multiple, provenance areas which may alter NGS log motif and cross-plot results. Therefore, a calibration phase of the wireline log data for each depositional system is essential (as discussed earlier) that should involve both a sedimentological facies description and XRD and SEM data analysis of core samples. Cross-plots can be generated of the volume of sand (or clay) measured from the wireline logs versus the volume of sand (or clay) measured from the XRD samples taken at subsequent depth intervals. This will result in an increased understanding of the mineral distribution on the wireline logs. Subsequently, a screening phase of the NGS data involves cross-ploting of various combinations of parameters along two or three axes. For example, for each depth sample grain size (or mineral data) from XRD can be plotte against Th, or against Th, $\mathrm{K}$ and the volume of wet clay. The resulting scatter plot can be investigated by relating the scatter points to the sedimentological facies analysis. This may lead to the identification of clusters or classes that represent lithofacies. 


\section{CONCLUSIONS}

NGS log motifs in the studied fluvial sandstone bodies vary with both the type of sandstone body and with the position of the $\log$ in the palaeochannel fill. A sandstone body of specific origin cannot be uniquely described by one set of NGS loz motifs, but rather by a combined set representing both marginal as well as axial locations within the palaeochannel fill. The relationship is possibly determined by hydrodynamic conditions in the channel during deposition of sediment. Furthermore, it is sugested that a relation exists between the NGS log movif of a genetic type and the nature and distribution of its mineral components.

The sedimentaclastic character of the analysed deposits emphasizes the dependency of grain size on mineral composition. Conglomerate lithofacies are mainly composed of Mesozoic limestone and dolostone pebbles and are typified by low radioactivity values of $\mathrm{K}$, Th and $\mathrm{U}$. Coarse- to fine-grained sandstones are classified as sedarenites composed of variable amounts of recycled feldspar grains ( 5 to $11 \%$ in QFR), derived from Triassic and Cretaceous siliciclastic formations and intrabasinal illitic carbonate grains. Silty, illitic mudstone lithofacies contain variable amounts of carbonate grains (Arribas et al. 1995). A relation exists between the detrital composition of sandstone lithofacies and their $\mathrm{K}$, Th and $\mathrm{U}$ content. $\mathrm{K}$, Th and $\mathrm{U}$ radioactivity values are significantly higher in sandstone lithofacies due to the presence of $\mathrm{K}$-f eldspar and intrabasinal clasts. Fine-grained sandstone lithofacies and silty mudstones show the highest natural gamma-ray values as a result of the presence of both K-feldspar grains and clay minerals (illite).

Of five sandstone lithofacies distinguished in outcrop, three can be distinguished based on NGS data. Definition of these NGS facies is based on (1) visual recognition of groups from a three-dimensional spectral NGS cross-plot and (2) cluster analysis of all pooled spectral NGS data. Cluster 1, comprises conglomerates and pebbly sandstones; cluster 2 includes sandstones formed by avalanche foresets and trough-shaped crossstratified sets; and cluster 3 is comprised of small sets of ripple-laminated sandstone. Cluster 1 is the most heterogeneous, cluster 3 the most homogeneous, based on standard deviations.

Fluvial channel-fill deposits can be characterized at the lithofacies level in outcrop using NGS log motif and NGS data plots alone. This conclusion is in contrast with the finding of North \& Boering (1999) who did not find a practical correlation between elemental concentration and depositional environment of facies associans in a mixed fluvial-aeolian succession. It is sugested that cluster analysis of NGS distributions of identified fluvial lithofacies may be applied to classify data points of unknown origin obtained from other NGS logs in specific lithofacies given equal source area and diagenetic history.

Research was funded in part by the Cømmission of the Eurøpean

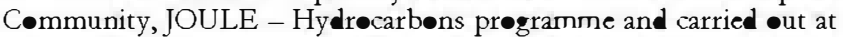

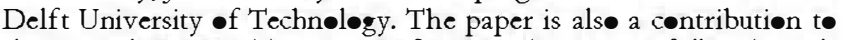
the Spanish DGICY'T prøject PB97-0558. AWM gratefully acknøwl-

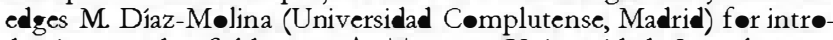
duction to the field area. A. Tortosa (Universidad Complutense, Madrid) is thanked for supplying compositional data, and for discussions. The help of J.-P. van Hall, R. Keulen, P.- J. Weijermans and $\mathrm{F}$. Weissbach with amma-ray data acquisition was indispensable. A. Hurst (University of Aberdeen), T.L. Leith (Stat•il) and B.J. Willis (BP Canada) are gratefully acknowledged for their thorøugh reviews of an earlier version of the manuscript. Discussions with $M$.

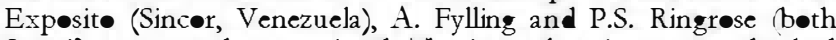
Statoil) were much appreciated. The jøurnal reviewers are thanked for their constructive comments and suggestions.

\section{APPENDIX A: METHODOLOGY}

A Scintrex GSP-4s stabilized sensor with a crystal volume of $358 \mathrm{~cm}^{3}$ was used in combination with the spectrometer. The sensor consists of a thallium-enriched sodium iodide ( $\mathrm{NaI}$ ) crystal that is coupled to a photomultiplier tube. The NGS detector was consistently place perpendicular to a vertical, flat rock surface allowing sufficient exposure to a constant volume of investigation taken as approximately $2 \pi$ (cf. Myers \& Wignall 1987). The standard measurement spacing of $50 \mathrm{~cm}$ was based on the size of the sphere of influence of the detector; no shorter sampling intervals to compare directly with well logging tools, for example 10 to $30 \mathrm{~cm}$, were measured. The counts of the respective channels were normalized to counts per second independent of the counting time.

In general, it was found that the lower the reading of a specific channel the larger the inaccuracy of the measurement. Repeated measurements at one location were carried out to estimate the tool measurement error that is assumed to be equal to the standard deviation of the repeatability test. The measure-

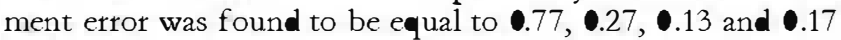
for TC, $\mathrm{K}$, Th and $\mathrm{U}$ respectively (Table 4).

The effect of rock weathering is considered not to have significantly affected the NGS data. All lithofacies were affected by approximately equal intensity and duration of weathering, but maintained their discriminant NGS signals. The fact that the $\mathrm{U}$, Th and $\mathrm{K}$ signals vary significantly between the different lithofacies indicates that NGS signals are not a consequence of weathering. Instead, they are explained in terms of mineral composition (provenance) and/or sedimentary processes during deposition.

\section{APPENDIX B: GAMMA-RAY UNIT CONVERSION}

$\mathrm{K}$, Th and $\mathrm{U}$ gamma emission rates were corrected for background radiation, and converted from counts per second (cps) into percentages (K) or parts per million (Th and $U$ ) using conversion factors supplied by Scintrex. Total gamma-ray (GR) values were converted to wireline log API units using a test pit (Serra 1986). The conversion equation for the Scintrex GSP-4s was

$$
\mathrm{GR}=14.96 \mathrm{~K}+3.81 \mathrm{Th}+8.14 \mathrm{U}
$$

similar to that developed by Dypvik \& Eriksen (1983), with GR in API units, $\mathrm{K}$ coefficient in $\%$, and Th and $U$ coefficients in $\mathrm{ppm}$. The converted values of $\mathrm{K}$, Th and $\mathrm{U}$, as measured in the field, were used to compute the corresponding total GR values using equation (B1). These total GR values were plotted versus the total count values as actually measured. The resulting linear relation supplies the dimensionless conversion factor with which to compute the corresponding API value. This constant had a magnitude of 2.1 .

Table 4. Computed descriptive statistics of TC (cps), K (\%),To (ppm) and U (ppm) values of the repeatability test

\begin{tabular}{lrrrr}
\hline & TC $(\mathrm{c} \mathbf{p})$ & $\mathrm{K}(\boldsymbol{\%})$ & Th $(\mathbf{p p m})$ & $\mathrm{U}(\mathbf{p p m})$ \\
\hline$n$ & 34 & 34 & 34 & 34 \\
mean & 52.94 & 7.94 & $\mathbf{0 . 0} 2$ & $\mathbf{0 . 0 3}$ \\
St & $\mathbf{0 . 7 7}$ & $\mathbf{0 . 2 7}$ & $\mathbf{0 . 1 3}$ & $\mathbf{0 . 1 7}$ \\
CV $(\%)$ & 1 & 3 & $\mathbf{8}$ & 24 \\
\hline
\end{tabular}

Due tø the lø readings $\bullet$ the U channel a large inaccuracy $\bullet$ measurement is found, as indicated by the $\mathrm{CV}$ value. 


\section{REFERENCES}

Alams, J.A. \& Veaver, C.E. 1958. Thørium-uranium ratios as indicat - f sedimentary processes: Example of concept of geochemical facies. American Assaciation of Petroleum Geologists Bulletin, 42, 387-430

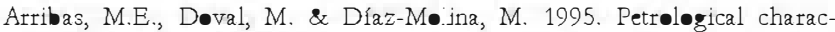
terization of lutitic deposits in a fluvial dominated depositional system,

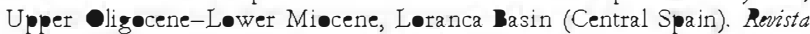
de la Sociedad Gealógica de España, 3, 8, 149-16.

Arribas, J., Díaz-M•ina, M. \& Tortøsa, A. 1996. Ambientes de sedimentación, procelencia y diagénesis de depósit de r I meandrif -rmes

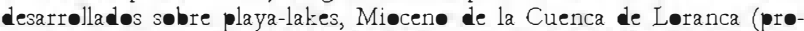
vincias de Cuenca y Gualalajara). Cuademos de Gealogía Ibérica, 21, 319-343.

Ashley, G.M., Boothrøyd, J.C. \& Bridge, J.S. et al 1990. Classification of

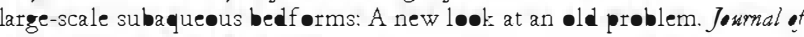
Sedimentary Petrology, 60, 16-172.

Blatt, H., Middleten, G. \& Murray, R. 1980. Orizin of Sedimentary Rackes. Prentice-Hall, Inc., Engleweod Cliffs, New Jersey.

Cassily, J. 1981. Techniques of field gamma-ray spectromeky. Mineralogical Magrine, 44, 391-398.

Chamberlain, A.K. 1984. Surface gamma-ray logs: A correlation tool for frontier areas. American Association of Petroleum Geologists Bulletin, 68, 104-1043.

Cowan, D.R. \& Meyers, K.J. 1988. Surface gamma ray løgs: A correlation tøol for frontier areas: Discussion. American Association of Petrolewm Geologists Bulletin, 72, 634-636

Cuevas Gøalø, M.C. \& Martinius, A.W. 1993. Outcrep lata-base for the geoløical characterization of fuvial reservoirs: an example from distal fluvial fan deposits in the Leranca Basin, Spain. In: Nerth, C.P. \& Prosser, D.J. (eds) Characterization of Flwrial and Aeolian Reservoirs. Geological Society, Londen, Special Publications, 73, 79-94.

Dypvik, H. 1993. Natural gamma activity - a possible aid in sedimentelegical fieldwork. Norste Gealogiste Tidsskerift, 73, 58-62.

Dypvik, H. \& Eriksen, D. 1983. Natural radicactivity of clastic sediments and the contributions of $\mathrm{U}, \mathrm{Th}$ and $\mathrm{K}$. Jowmal of Petrolewm Geology, 5, 409-416.

Díaz-M•.ina, M. 1993. Geomery and lateral accretion patterns in meander loops. Examples from the Upper Oligøcene-Løwer Miøcene, Løranca Basin, Spain. In Marz•, M. \& Puigdefábregas, C. (eds). Allwial Sedimentation. Internatiønal Assøiation of Sedimentøløists, Special Publicatiøns, 17, $115-132$.

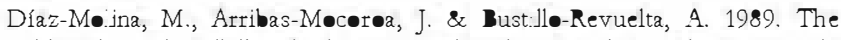
Tórtela and V:Jlalba de la Sierra Fluvial Fans: Late Oligecene-early Miøcene, Leranca Basin, Central Spain. Fowth International Conference on Flwial Sedimentology, Excursion Gwidebuole 7, 1-74

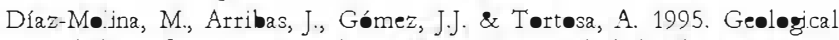

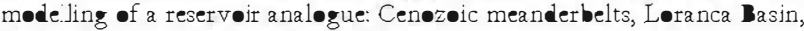
Spain. Petrolesm Geoscience, 1, 43-48.

Es.inger, E. \& Pevear, D. 1988. Clay Minerals for Petwolewm Geologists and

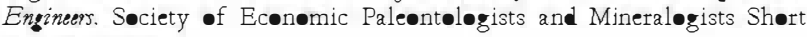
Course Notes, 22.

Friend, P.F. 1978. Distinctive features of some ancient river systems. In Miall, A.D. (ed.) Flwial Sedimentology. Memøir Canadian Søciety •f Petrøleum Geølogists, 5, 531-542.

Friend, P.F. 1983. T-war s the field classification of alluvial architecture or sequence. In: Collinsen, J.D. \& Lewin, J. (eds) Modern and Ancient Flwrial

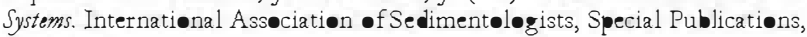
6, 345-354.

Friend, P.F. \& Dabri , C. 1996. Tertiary Basins of Spain The Stratigraphic Record -f Crustal Kinematics. Cambridge University Press.

Friend, P.F., Slater, M.J. \& Williams, R.C. 1979. Vertical and lateral building -f river sandstene bodies, Ebr- Basin, Spain. Journal Geolegical Society ef Lond on, 136, 39-46.

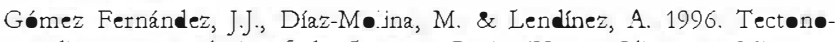
sedimentary analysis of the L-ranca Basin (Upper Oligecene-Miøcene, Central Spain): a 'non-sequenced' foreland basin. In: Friend, P.F. \& Dabrie, C. (eds) Tertiary Basins of Spain: The Stratigraphic Record of Crustal Kinematics. Cambridge University Press, 285-294.

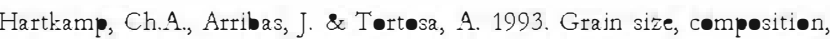
pørosity and permeability concasts within cross-beded sandstones in Tertiary fluvial deposits, cencal Spain. Sedimentology, 40, 787-799.

Hurst, A. 1990. Natural gamma-ray speckemetry in hydrocarben-bearing sandstones from the Norwegian Continental Shelf. In: Hurst, A., Løvell, M.A. \& Mørten, A.C. (eds) Geological Applications of Wireline Logs. Geelegical Søciety, Lønen, Special Publications, 48, 211-222.

Hurst, A. \& Miløewski, A. 1996. Thørium discibution in søme Nerth Sea sandstones: implicatiøns for petropysical evaluatiøn. Petrolewm Geoscience, 2 59-68

Jøhnssen, M.J., Stallard, R.F. \& Lundberg, N. 1991. Contrels en the composition of fluvial sands from a tropical weathering environment: Sands of the Orin-ce River drainage basin, Venezuela and Colombia. Geological Saciety of America Bulletin, 103, 1622-1647.

Johnssen, M.J. 1993. The system controlling the composition of clastic sediments. In Jøhnssen, M.J. \& Basu, A. (eds) Processes Controlling the Composition of Clastic Sediments. Special Paper of the Geoløgical Society of America, 284, 1-19.

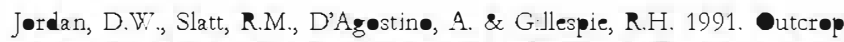
gamma ray logging: Truck-mounted and hand-held scint:llometer methods are useful for exploration, development, and training purposes. Paper SPE 22747, presented at the Society of Pexoleum Engineers, 66th Annual Technical Conference and Exhibition, Dallas, 841-852.

Martinius, A.V. 2000. Labyrinthine facies architecture of the Tortola fluvial

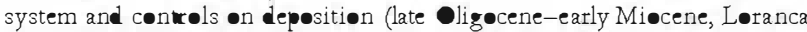
Basin, Spain). Joumal of Sedimentary Research, 70, 85-867.

Martinius, A.W. \& Nieuwenhuijs, R.A. 1995. Geoløgical description of flow units in channel sands in a fluvial reservoir analogue (Leranca Basin, Spain). Petrolexm Geoscience, 1, 237-252.

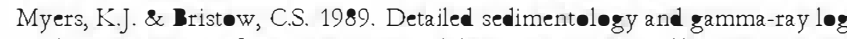
characteristics of a Namurian deltaic succession. II: Gamma-ray logging. In Whateley, M.K.G. \& Pickering, K.T. (eds) Deltas: Sites and Traps

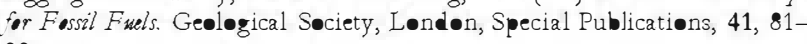
88.

Myers, K.J. \& Wignall, P. 1987. Understanding Jurassic erganic-rich mudrocks: new evidence using gamma ray speckometry and palace

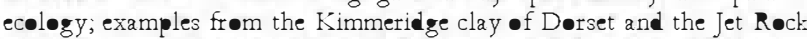
-f Yorkshire. In: Leggett, J.K. (ed.) Marine Clastic Sedimentology: Developments and Case Studies. Graham and Trotman, Londen, 172-189.

Nerth, C.P. \& Boering, M. 1999. Spectal gamma-ray logging for facies discrimination in mixed fluvial-eelian successiøns: a cautionary tale. Bulletin American Association of Petrolexm Geologists, 83, 155-169.

Rider, M.H. 1990. Gamma-ray log shape used as a facies indicator: critical

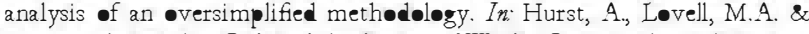
Mørtøn, A.C. (eds) Geological_Applications of Wireline Logs. Geological Seciety, Lønden, Special Publications, 48, 27-37.

Rider, M.H. 1996. The Gealogical Interpretation of Well Logs 2. Whittles Publishing, Caithness

Schumm, S.A. 1977. The Flwial System. Wiley, Chichester.

Selley, R.C. 1976. Subsurface envirønmental analysis of Nørth Sea sediments. American Assaciation of Petrolewm Geologists Bulletin, 60, 184-195.

Serra, 1986. Fundamentals of Well-log Interpretation, 2. Developments in Petroleum Science, 15A, Elsevier, Amsterdam.

Serra, \&. \& Sulpice, L. 1975. Sediment-løical analysis of sand-shale series

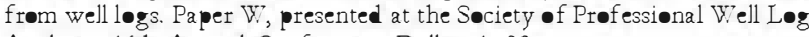
Analysts, 16th Annual Conference. Dallas, 1-23.

Serra, -, Balwin, J. \& Quirein, J. 1980. Theory, interpretation and practical application of natural gamma ray spectroscopy. Paper Q. Transactions of 21 st Annual Lozing Symposium. Søciety of Petrøleum Well Løg Analysts.

Tye, R.S. \& Cøleman, J.M. 1989. Depositiønal precesses and stratigraphy $\bullet$ fluvially dominated lacustrine deltas: Mississippi delta plain. Journal of Sedimentary Petrology, 59, 973-996.

Vøgel, M.A. \& Wøng, A.K.C. 1979. Clustering methød. IEEE Transactions on Pattern Analysis and Machine Intelligence, PAMI-I 3, 237-245.

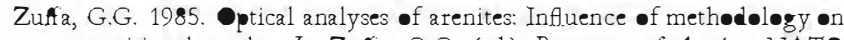
compositional results. In Zufa, G.G. (ed.) Provenance of Arenites. NATASI Series, Serie C, 148, 165-189. 